\title{
POSTAVENIE NITRIANSKEHO SAMOSPRÁVNEHO KRAJA Z POHLADU OBJEKTÍVNEJ CHUDOBY
}

\author{
Nadežda Krajmerová, Ján Veselovský
}

\begin{abstract}
The main aim of our thesis is to analyse and assess the districts of Nitra self-governing region from the viewpoint of poverty. The analysis is based on indicators gained from Statistical Office of the Slovak Republic and census of inhabitants, houses and flats in 2011. All of these indicators are either of an economical aspect, such as long term unemployment, extent of registered unemployment, extent of economic activity, entrepreneurship and the flat reconstruction intensity or social aspect e.g. a low degree of education and gypsy ethnic group. Moreover, demographic aspects have been involved into our research, such as viviparity, mortality and average age. We have found out that the poorest districts occur in the south of Nitra region, in contrast to the north area which is considered to be the richest part of Nitra region.
\end{abstract}

Keywords: objective poverty, poverty, districts, Nitra Self-governing Region

\section{Úvod}

Chudoba ako sociálny problém sa v súčasnosti dostáva stále viac do popredia spoločenského vnímania. Prispieva $\mathrm{k}$ tomu hlavne odlišný rozvoj jednotlivých regiónov Slovenska, čo zapríčiňuje rozdielnu možnost' uplatnenia sa na trhu práce.

Ciel'om príspevku je upriamit' pozornost' na rozmanité pomery v okresoch Nitrianskeho samosprávneho kraja (NSK), na základe ekonomických indikátorov (dlhodobá nezamestnanost', miera evidovanej nezamestnanosti, miera ekonomickej aktivity, podnikanie a intenzita obnovy bytov), sociálnych indikátorov (rómske etnikum, nízka úroveň vzdelania) a demografických indikátorov (živorodost', úmrtnost' a priemerný vek). Dané indikátory nám pomohli hlbšie analyzovat' úroven̆ chudoby v kraji.

\section{Teoreticko-metodické východiská}

Chudoba je súčasným problémom spoločnosti. Zaoberá sa ňou vel'ké množstvo autorov, ktorí sa ju snažili definovat'.

V zmysle Žilovej (2004) chudoba nie je disproporcia medzi ašpiráciami a dostupnými prostriedkami na ich naplnenie. Je to predovšetkým vzt'ah medzi l'ud'mi, sociálny status. 
Je to stav človeka, ktorý nevlastní hmotný majetok alebo má nedostatok financií. Vyskytuje sa vtedy, ked' si l'udia nevedia zabezpečit' primárne potreby (Tomeš, 2010).

U Townsenda (1987) chudoba predstavuje nedostatok prostriedkov pre takú výživu, také činnosti a životné podmienky, aké sú bežné v spoločnostiach, ku ktorým l'udia patria.

Disponibilný príjem NSK je na úrovni $597,99 €$, čo je v porovnaní $\mathrm{s}$ priemerným disponibilným príjmom Slovenskej republiky o $17,93 €$ menej. Z hladiska všetkých krajov Slovenska je disponibilný príjem Nitrianskeho kraja tretí najnižší na Slovensku (www.statistics.sk).

Miera evidovanej nezamestnanosti v NSK dosahovala k 31.12.2017 hodnotu 4,05 \%, čo je o 2,91\% menej ako v roku 2016 (www.statistics.sk). S touto hodnotou radíme Nitriansky kraj na štvrté miesto $\mathrm{s}$ najnižšou mierou nezamestnanosti v rámci všetkých krajov SR.

V roku 2017 NSK, zo všetkých krajov na Slovensku, zaznamenal najvyššiu mieru úbytku obyvatel'stva, a to -1495 obyvatel'ov, čo predstavovalo prirodzený úbytok $-2,2 \%$. Z tohto kraja sa vyst'ahovalo 3789 obyvatel'ov, čo predstavovalo hodnotu 5,576 \%o a naopak prist'ahovalo 3 197, čo v promile vykazovala hodnota 4,705 \%. Ako môžeme vidiet', vyst'ahovaní z trvalého pobytu prevyšovali pristahovaných o $0,871 \%$. V kraji bolo uzatvorených 3684 sobášov, tzn. 5,422 \% a 1300 rozvodov, čo vykazuje hodnota $1,913 \%$. Živonarodené deti v Nitrianskom kraji predstavovali druhú najnižšiu hodnotu zo všetkých krajov Slovenska, a to 6 231, čo znamená 9,17\%o, úmrtnost' dosahovala hodnotu 7726 obyvatel'ov, čo predstavovalo 11,37 \% a znamená to, že v kraji je najvyššia úmrtnost' na Slovensku, ktorá presahuje celkovú úmrtnost' Slovenska, ktorá dosahuje hodnotu 9,915\%. Znamená to rozdiel až o 1,455\%o (www.statistics.sk).

$\mathrm{Na}$ základe výsledkov EU SILC 2016 bol priemerný disponibilný ekvivalentný príjem domácností v Nitrianskom kraji 597,99 € na mesiac, čo je tretí najnižší príjem po Prešovskom a Banskobystrickom kraji. Podl'a uvedenej priemernej mesačnej mzdy sme zistili, že v kraji sa nachádza 96303 l’udí pod hranicou chudoby, čo radí kraj na štvrté miesto po Prešovskom, Košickom a Banskobystrickom kraji (www.statistics.sk). V zmysle Falt’ana a Pašiaka (2004) je NSK častou Slovenska, ktorému hovoríme pás chudoby.

\section{Objektívna chudoba v Nitrianskom samosprávnom kraji}

Objektívna chudoba reflektuje spoločenskú zhodu alebo politické odhodlanie na poskytnutie konkrétnych výdavkov spoločnosti. Tento typ chudoby sa radí medzi menej početné ako subjektívna chudoba. Pomyselná hranica chudoby je daná z vonku a kompletne sa vyhýba l'ud'om, s ktorými súvisí. Je podriadená sociálnemu a politickému súladu, ktorý sa nachádza $\mathrm{v}$ hlbšom ponímaní spoločnosti. Je ovplyvnená sociálnymi inštitúciami a štátom (Mareš, 1999). 
Aj ked' je v problematike chudoby prítomné vel'ké množstvo rozmanitých prístupov a nejednotnost', dá sa povedat', že sa objektívny prístup stáva primárnym, dobre hodnoteným a rovnako aj porovnatel'ným postupom merania chudoby. Na základe vhodnej porovnatel'nosti a meratel'nosti sme si za hlavnú a rozhodujúcu úroveň chudoby stanovili objektívnu dimenziu $\mathrm{v}$ okresoch Nitrianskeho kraja.

Objektívna dimenzia vyplýva $\mathrm{z}$ ohraničenia chudoby prostredníctvom aspektov nezávislých na mienke jednotlivcov, ktorí sa za chudobných pokladajú. Objektívna dimenzia sleduje chudobu zvonka, s vylúčením kontroly zo strany ludí, na ktorých sa daný problém vzt’ahuje.

Stanovenie stupňa chudoby prostredníctvom danej dimenzie vyplýva $\mathrm{z}$ hl'adiska jej stupňa pomocou vybratých ukazovatel'ov spoliehajúcich sa na dáta zo štatistík (Veselovský, 2012).

\section{Indikátory objektívnej dimenzie}

$\mathrm{Na}$ základe dostupných údajov a materiálov zo Štatistického úradu Slovenskej republiky a študijnej literatúry, sme vybrali 10 indikátorov, podla ktorých sme vypracovali tri skupiny objektívnej dimenzie tvorené ekonomickým, demografickým a sociálnym aspektom, ovplyvňujúcim chudobu v NSK (Veselovský, 2012).

$\mathrm{K}$ ekonomickému aspektu (zameraný na materiálne udržiavanie a zabezpečovanie l'udského života; oblast' spoločenskej činnosti, prostredníctvom ktorej sa vyrábajú, rozdel'ujú, vymieňajú a spotrebúvajú úžitkové hodnoty) sme zaradili 5 indikátorov ovplyvňujúcim objektívnu dimenziu chudoby (tab. 1).

Tab. 1: Ekonomické indikátory ovplyvňujúce objektívnu dimenziu chudoby v NSK Table 1: Economic indicators affecting the objective dimension of poverty in NSK

\begin{tabular}{|l|l|}
\hline \multicolumn{1}{|c|}{ Indikátory } & \multicolumn{1}{c|}{ Charakteristika } \\
\hline $\begin{array}{l}\text { miera ekonomickej } \\
\text { aktivity }\end{array}$ & podiel EAO z celkového počtu obyvatel'ov v \% \\
\hline podnikanie & $\begin{array}{l}\text { počet živnostníkov na } 100 \text { obyvatel'ov v produktívnom veku } \\
\text { v \% }\end{array}$ \\
\hline intenzita obnovy bytov & počet nových bytov na 1000 obyvatel'ov v \%o \\
\hline miera nezamestnanosti & podiel EN na 100 obyvatel'ov v produktívnom veku v \% \\
\hline dlhodobá nezamestnanost' & $\begin{array}{l}\text { podiel EN nad } 12 \text { mesiacov v evidencii z celkového počtu } \\
\text { EN v } \%\end{array}$ \\
\hline
\end{tabular}

Zdroj: Veselovský, 2012

\section{Miera ekonomickej aktivity}

Miera ekonomickej aktivity predstavuje na Slovensku 50,08 \%, z celkového počtu obyvatel'ov. Pozitívnym faktom je, že miera ekonomickej aktivity v kraji, je 
o 1,2\% vyššia, t.j. 51,28 \% z celkovým počtom 348020 ekonomicky aktívnych obyvatel'ov (www.statistics.sk).

Z okresov Nitrianskeho kraja sa, v grafe 1, pod priemernou hodnotou kraja nachádzajú okresy Levice (LV- 49,59 \% - 55417 ekonomicky aktívnych obyvatel'ov) a Zlaté Moravce (ZM- 50,32 \% - 20462 EAO). Najbližšie sa k hodnote kraja priblížil okres Nitra (NR- 51,45 \% - 82851 EAO), no najvyššiu mieru ekonomickej aktivity dosiahli okresy Topol'čany (TO- 53,58 \% - 37840 EAO) a Komárno (KN- 52,11 \% - 53307 EAO), ktoré svojimi hodnotami prevýšili priemernú hodnotu celého Nitrianskeho kraja. Topol'čany prevýšili priemer kraja o 2,3 \% a Komárno o $0,83 \%$. Avšak, pozitívnymi hodnotami sa tiež vyznačujú okresy Nové Zámky (NZ- 51,03 \% - 71528 EAO) a Šal'a (SA- 51,03 \% - 26615 EAO).

Graf 1: Miera ekonomickej aktivity (\%) v okresoch NSK v roku 2017 Graph 1: The rate of economic activity (\%) in NSK districts in 2017

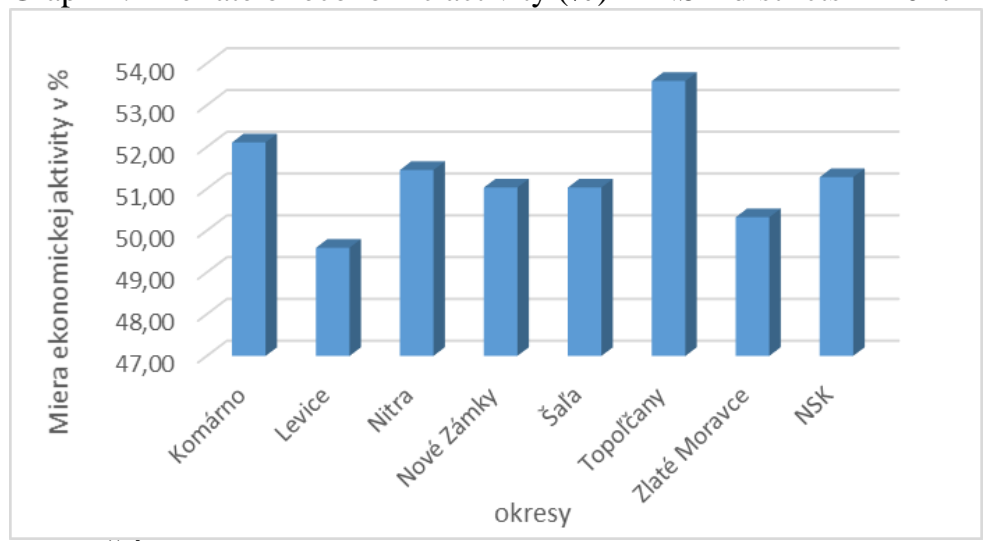

Zdroj: ŠÚ SR, 2018, spracovala Nadežda Krajmerová, 2018

\section{Podnikanie}

V grafe 2 vidíme, že množstvo živnostníkov v okresoch kladne vplýva na ekonomickú aktivitu celého kraja. Na vytvorenie nových pracovných príležitostí výrazne prispievajú živnostníci, tzn. čím väčšie množstvo živnostníkov, tým je menší počet nezamestnaných a menšie riziko chudoby (Veselovský, 2012).

V NSK pripadá na 100 obyvatel'ov v produktívnom veku, v priemere 9,86 \% živnostníkov. Spomedzi okresov, ktoré dosiahli vyššie hodnoty ako priemer Nitrianskeho kraja, sú to Levice (10,54 \% - 7400 živnostníkov), NR (10,62 \% - 10 650 živnostníkov) a ZM, ktoré dosiahli najvyšší percentuálny podiel zo všetkých okresov sledovaného kraja (11,59 \% - 2948 živnostníkov). Naopak, najnižšie hodnoty, nie vel'mi priaznivé pre prosperitu regiónu dosiahli okresy KN $(9,36 \%$ 6010 živnostníkov), NZ (8,48 \% - 7431$)$ a SA (9,40\%). 
Graf 2: Podiel živnostníkov (\%) v okresoch NSK v roku 2017

Graph 2: Share of tradesmen (\%) in NSK districts in 2017

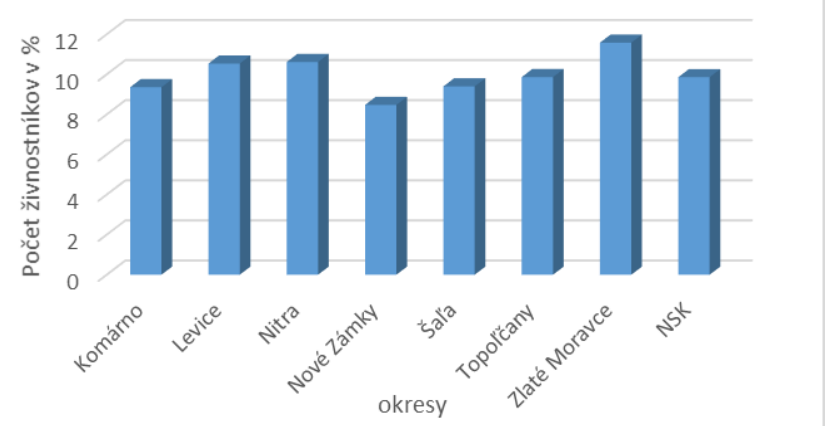

Zdroj: ŠÚ SR, 2018, spracovala Nadežda Krajmerová, 2018

\section{Intenzita obnovy bytov}

Daný indikátor najlepšie charakterizuje celkový počet nových bytov na 1000 obyvatel'ov stredného stavu (\%o) (Némethová, Pulpitlová, 1999), pričom sme ho pozorovali v okresoch Nitrianskeho kraja v roku 2011 (hodnoty indikátora sa prepočítavajú iba raz za 10 rokov).

V grafe 3 môžeme vidiet', že priemerná hodnota výstavby a obnovy bytov v Nitrianskom kraji v roku 2011 je 2,10 \%, čo v absolútnych hodnotách predstavuje 1433 novopostavených bytov. Najvyšší počet postavených bytov, vyšší ako priemer kraja bol v okrese Nitra (3,07 \% - 493 bytov), Šala $(2,77 \%$ 145 bytov), Topol'čany (2,31 \% - 164 bytov) a ZM (2,77 \% - 113 bytov). Podpriemerný počet novopostavených bytov, pod úrovňou hodnoty kraja, mali okresy KN (1,09\%o), LV (1,60 \%o) a NZ (1,60\%o).

Graf 3: Intenzita obnovy bytov (\%) v NSK v roku 2011

Graph 3: Renovation intensity of flats (\%) in NSK in 2011

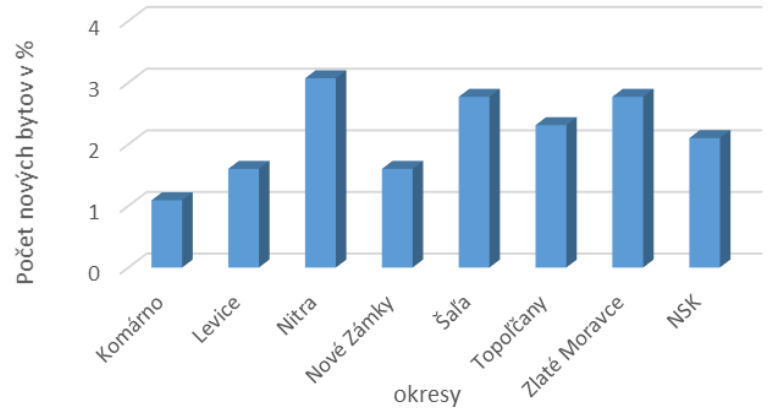

Zdroj: SODB 2011, spracovala Nadežda Krajmerová, 2018 


\section{Miera evidovanej nezamestnanosti}

Mieru nezamestnanosti považujeme za najviac používaný a základný indikátor nezamestnanosti, ktorý znázorňuje podiel evidovaných nezamestnaných z celkového počtu ekonomicky aktívnych obyvatel'ov v (\%) (Veselovský, 2012).

Graf 4 nám ukazuje, že priemerná hodnota miery nezamestnanosti predstavovala v NSK hodnotu 4,05\%. Najviac sa k priemeru kraju priblížil okres Topol'čany, ktorého hodnota predstavovala 4,08 \% nezamestnaných. Nad priemerom kraju sa nachádzali okresy Levice $(5,44 \%)$, Komárno $(5,24 \%)$, a Topol’čany $(4,08 \%)$. Podpriemerné hodnoty (kladné z hl'adiska chudoby) môžeme vidiet' v okresoch ZM (3,90 \%), NZ (3,71\%), SA (3,32 \%), a najnižšiu hodnotu evidovanej nezamestnanosti dosiahol okres NR s hodnotou iba $2,90 \%$.

Graf 4: Miera evidovanej nezamestnanosti (\%) v okresoch NSK 2017

Graph 4: Registered unemployment rate (\%) in NSK districts in 2017

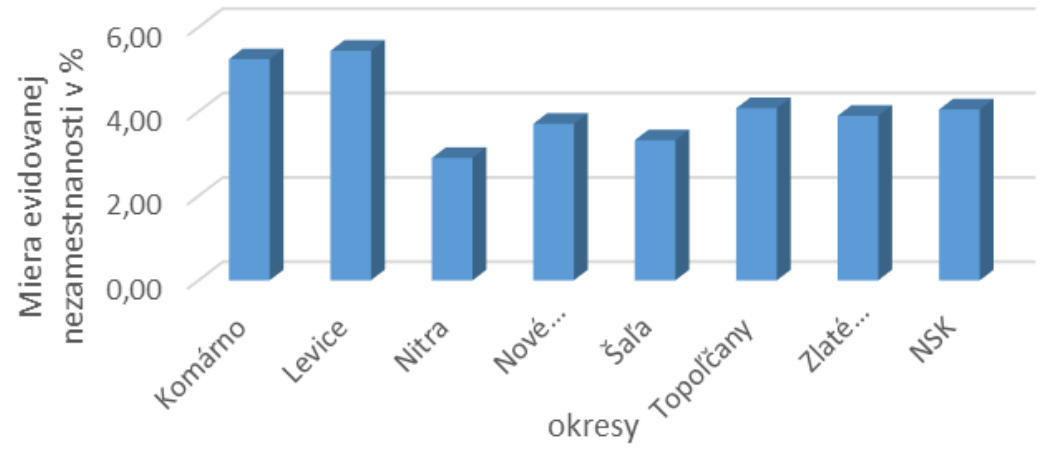

Zdroj: ŠÚ SR, 2018, spracovala Nadežda Krajmerová, 2018

\section{Dlhodobá nezamestnanost'}

Dlhodobá nezamestnanost' je najzávažnejším problémom nezamestnanosti. Za dlhodobo nezamestnaného považujeme toho, kto je $\mathrm{v}$ evidencii uchádzačov viac ako 12 mesiacov. Vyjadruje sa podielom ekonomicky neaktívnych obyvatel'ov nad 12 mesiacov z celkového počtu ekonomicky neaktívnych (\%).

Graf 5 nám ukazuje, že v NSK v roku 2017 dosahovala dlhodobá nezamestnanost' hodnotu 34,63 \%, t.j. 17949 osôb dlhodobo bez práce. Najvyššie hodnoty dlhodobej nezamestnanosti $\mathrm{v}$ okresoch Nitrianskeho kraja (nad priemerom kraja) dosahovali okresy Komárno (46,00\%) a Levice $(45,00 \%)$. Pod priemerom kraja sa nachádzali okresy ZM (33,14 \%), TO (30,96 \%), NZ (27,55 $\%)$, NR $(21,54 \%)$ a SA $(27,13 \%)$. 
Graf 5: Dlhodobá nezamestnanost' (\%) v okresoch NSK v roku 2017

Graph 5: Long-term unemployment (\%) in NSK districts in 2017

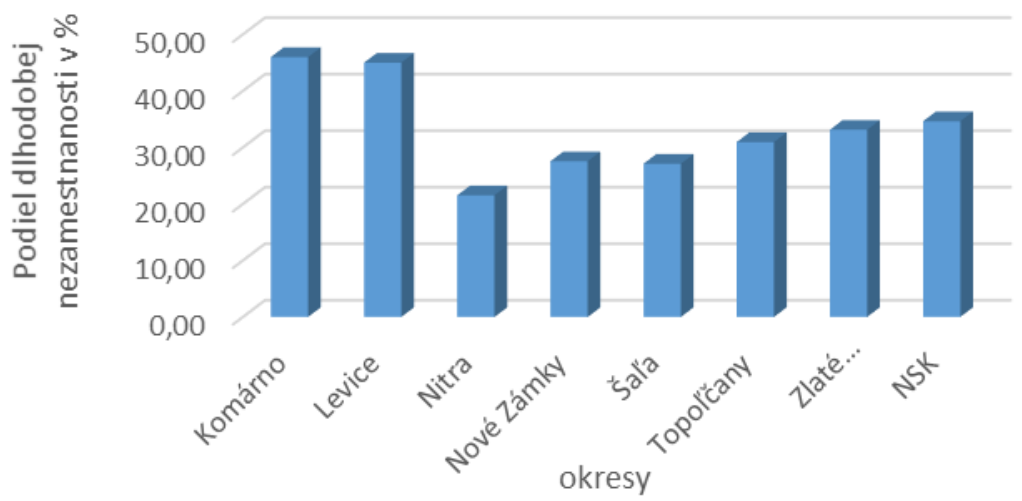

Zdroj: ŠÚ SR, 2018, spracovala Nadežda Krajmerová, 2018

K demografickému aspektu (jeho predmetom sú všetky udalosti a procesy, ktoré súvisia $\mathrm{s}$ reprodukciou l'udských populácií) sme zaradili 3 indikátory ovplyvňujúce objektívnu dimenziu chudoby (tab. 2).

Tab. 2: Demografické indikátory ovplyvňujúce objektívnu chudoby v NSK Table 2: Demographic indicators influencing objective poverty in NSK

\begin{tabular}{|l|l|}
\hline \multicolumn{1}{|c|}{ Indikátory } & \multicolumn{1}{c|}{ Charakteristika } \\
\hline živorodost' & počet živonarodených na 1000 obyvatel'ov v \%o \\
\hline priemerný vek & priemerný vek obyvatel'stva (roky) \\
\hline úmrtnost' & počet zomrelých na 1000 obyvatel'ov v \%o \\
\hline
\end{tabular}

Zdroj: Veselovský, 2012

\section{Živorodost'}

Živorodost' je rozhodujúcim ukazovatel'om reprodukcie obyvatel'stva, ktorý odzrkadl'uje počet živonarodených na 1000 obyvatel'ov stredného stavu v (\%o). Odráža ekonomickú situáciu, pomery v rodine, sociálne a demografické správanie jednotlivca v spoločnosti, čím môže spôsobit' aj chudobu (Czaková, 2007).

$\mathrm{V}$ grafe 6 vidíme, že v okresoch NSK sa najnegatívnejšie prejavila situácia v okrese Komárno $(8,08$ \%o živonarodených), Topol’čany $(8,701 \%$ ) a Nové Zámky $(8,741 \%$ o), ked’že priemerná hodnota celého NSK dosiahla hodnotu 9,17 \%. Hodnota, ktorá sa najviac približovala k hodnote kraja bola v okrese LV. 
Graf 6: Podiel živonarodených (\%o) v okresoch NSKv roku 2017

Graph 6: Share of live births (\%o) in NSK districts in 2017

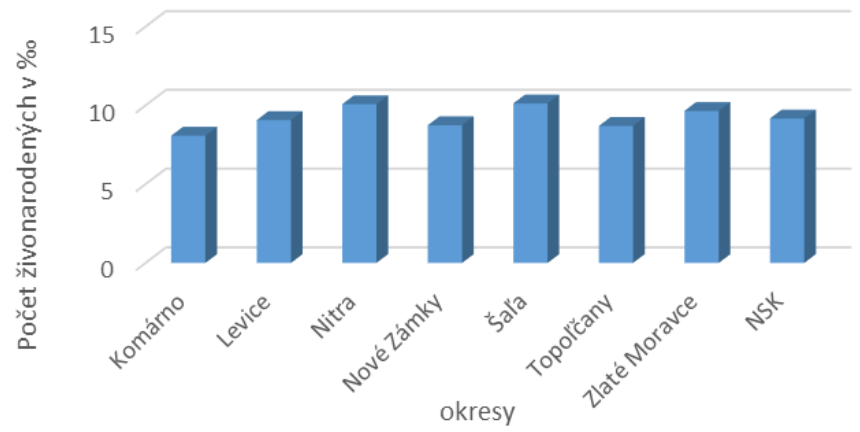

Zdroj: ŠÚ SR, 2018, spracovala Nadežda Krajmerová, 2018

\section{Priemerný vek}

Najväčšou spoločenskou výzvou a vymoženost'ou súčasnej doby je podl'a Bacsó (2008) predlžovanie dížky života.

Jurčová (2005) opisuje priemerný vek ako vážený aritmetický priemer počtu rokov, ktorých sa členovia určitej populácie dožili do konkrétneho momentu.

V grafe 7 vidíme, že v NSK sa priemerný vek obyvatel'ov vyšplhal na hodnotu 42,22 rokov. Okresy s najvyšším priemerným vekom sú Nové Zámky (42,79 rokov), Komárno (42,75 rokov) a Zlaté Moravce (42,36 rokov). Najnižšie hodnoty priemerného veku sú v okresoch Nitra (41,55 rokov) a okres Šal'a (41,55 rokov).

Graf 7: Priemerný vek (v rokoch) v okresoch NSK v roku 2017

Graph 7: Average age (in years) in NSK districts in 2017

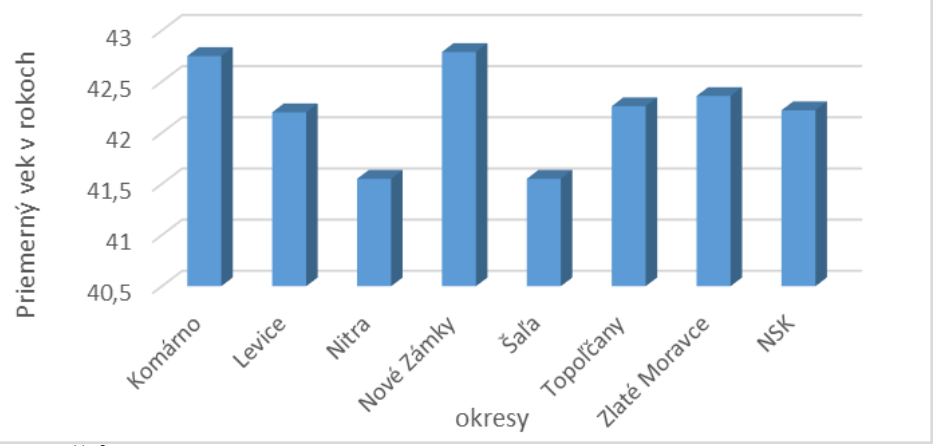

Zdroj: ŠÚ SR, 2018, spracovala Nadežda Krajmerová, 2018 


\section{Úmrtnost'}

Riziko chudoby sa znižuje predlžovaním strednej dížky života, zvyšovaním priemerného veku a tým dochádza $\mathrm{k}$ znižovaniu úmrtnosti. St’ažený prístup $\mathrm{k}$ zdravotnej, sociálnej pomoci či k adekvátnej výžive (hlavne u starších obyvatel'ov) majú na svedomí nedostatočné ekonomické zdroje, ktoré sa prejavujú zvýšenou chorobnost'ou a následnou úmrtnost'ou (Vilinová, Soták, 2008).

Graf 8 nám približuje situáciu úmrtnosti $\mathrm{v}$ okresoch NSK. Úmrtnost' $\mathrm{v}$ Nitrianskom kraji dosiahla úroveň $11,37 \%$. Spomedzi okresov sa na podobnej úrovni nachádzal okres Šal'a (11,508 \%) a okres Topol’čany (11,018 \%o). Najvyššiu mieru úmrtnosti dosiahol okres Nové Zámky (12,293 \%o). Na podobnej úrovni sa nachádzal okres Komárno (12,024 \%o). O niečo nižšie hodnoty zaznamenali okresy Levice (11,924 \%o), Zlaté Moravce (11,888 \%o), Šal'a (11,508 $\%$ ) a Topol'čany $(11,018 \%)$.

Graf 8: Úmrtnost' (\%o) v okresoch NSK v roku 2017

Graph 8: Mortality (\%) in NSK districts in 2017

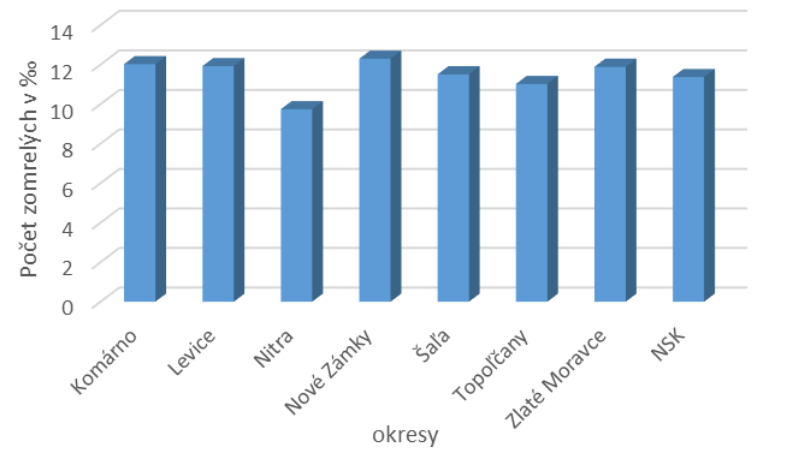

Zdroj: ŠÚ SR, 2018, spracovala Nadežda Krajmerová, 2018

K sociálnemu aspektu sme zaradili 2 indikátory ovplyvňujúce objektívnu dimenziu chudoby (tab. 3).

Tab. 3: Sociálne indikátory

table 3: Social indicators

\begin{tabular}{|l|l|}
\hline \multicolumn{1}{|c|}{ Indikátory } & \multicolumn{1}{c|}{ Charakteristika } \\
\hline rómske etnikum & podiel rómskeho etnika $\mathrm{v} \%$ \\
\hline nízky stupeň vzdelania & $\begin{array}{l}\text { podiel obyvatel'ov so základným vzdelaním na počte } \\
\text { obyvatel’ov starších ako 15 rokov v \% }\end{array}$ \\
\hline
\end{tabular}

Zdroj: Veselovský, 2012 


\section{Rómske etnikum}

V rôznych krajinách je významným prvkom štruktúry chudoby a nerovnosti etnická príslušnost'. Na Slovensku je chudoba mnohokrát prirad'ovaná $\mathrm{k}$ Rómom, a to primárne kvôli ich nedostatočnému vzdelaniu či spôsobilosti, ktoré ich znevýhodňujú pri zamestnaní sa (Michálek, 2005).

V grafe 9 vidíme, že v NSK sa $\mathrm{k}$ rómskej národnosti prihlásilo iba $0,58 \%$ Rómov, čo v absolútnych číslach vykazuje 3987 Rómov, a je to o 1,38 \% menej ako na celom území Slovenska. Najbližšie k priemeru kraja sa priblížil okres Nitra (0,47 \% - 745 Rómov) a Nové Zámky (0,48 \% - 691 Rómov). Vysoké percento Rómov sa k svojej národnosti priznalo v okrese Komárno $(1,20 \%$ - 1250 Rómov).

Graf 9: Rómske etnikum (\%) v okresoch NSK v roku 2011

Graph 9: Roma ethnicity (\%) in NSK districts in 2011

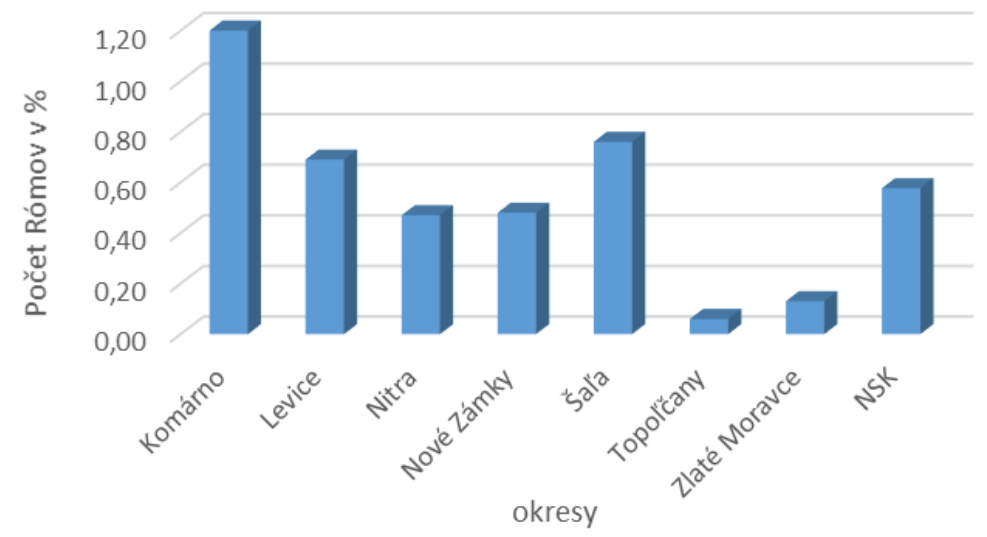

Zdroj: SODB 2011, spracovala Nadežda Krajmerová, 2018

\section{Nizky stupen̆ vzdelania}

Nielen vo vyspelých štátoch sveta, ale aj na Slovensku, či dokonca v Nitrianskom kraji sa začína nízke vzdelanie odzrkadl'ovat' na výške mesačnej mzdy. L'udia s nízkym stupňom vzdelania môžu tiež vytvárat' skupinu ohrozenú chudobou. Túto situáciu podmieňuje fakt, že spoločnost' sa mení na informačnú, v dôsledku čoho nastáva kvalitatívna nezamestnanost', determinovaná nedostatočným vzdelaním (Rochovská, 2004).

Tento indikátor môžeme definovat' ako podiel obyvatel'ov s najnižším základným vzdelaním na počte obyvatel’ov starších ako 15 rokov (\%) (Veselovský, 2012).

Graf 10 nám ukazuje, že na území NSK dosiahol priemer obyvatel'ov s 
nízkym vzdelaním, resp. zo základným, hodnotu 16,98 \%. Zo všetkých okresov kraja sa najvyšší počet obyvatel'ov s nízkym vzdelaním nachádza $\mathrm{v}$ okrese Komárno $(23,80 \%)$. Vysoké percento tiež zaznamenali okresy Levice $(21,20 \%)$, Šala $(20,20 \%)$ a Nové Zámky (20,12 \%).

Graf 10: Nízky stupeň vzdelania (\%) v okresoch NSK v roku 2011

Graph 10: Low level of education (\%) in NSK districts in 2011

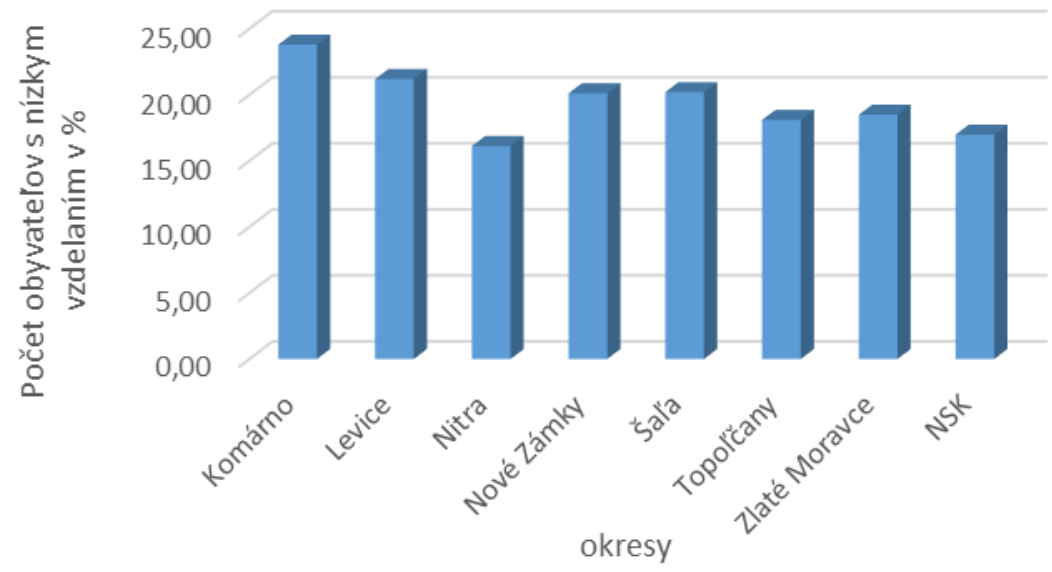

Zdroj: SODB 2011, spracovala Nadežda Krajmerová, 2018

Záver

Miera rizika chudoby (na základe sociálno-ekonomická situácia a tiež vývoja príjmovej situácie v domácnostiach) v kraji dosiahla za rok $2017-14,6 \%$, čo predstavuje vyššiu mieru rizika chudoby ako priemer Slovenskej republiky $(12,7 \%)$ (www.statistics.sk). Zo všetkých krajov Slovenska sa NSK ocitol na štvrtej priečke $\mathrm{v}$ poradí, s najvyššou mierou rizika chudoby. $\mathrm{V}$ absolútnych číslach to predstavuje celkom 96303 osôb, ktoré sa dostali do rizika chudoby v Nitrianskom kraji.

Z hl'adiska priestorovej diferenciácie chudoby $\mathrm{v}$ okresoch NSK sa nám najlepšie, resp. najkladnejšie, ukazujú okresy severozápadnej až centrálnej časti kraja. Konkrétne sú to okresy Nitra, Šal'a a Topol'čany, o ktorých môžeme povedat', že patria medzi okresy s najkladnejšími indikátormi z pohl'adu merania chudoby. Okresy s nepriaznivou diferenciáciou chudoby sú sústredené na juhu daného kraja. Medzi tieto zarad’ujeme okresy Komárno, Levice a Nové Zámky, ktoré na základe určitých indikátorov dosiahli najmenej uspokojivé výsledky.

Z uvedenej analýzy okresov Nitrianskeho kraja môžeme povedat', že 
bohatšie okresy sú lokalizované v severnej časti, a chudobnejšie okresy sú usporiadané v južnej časti Nitrianskeho kraja. Je to spôsobené tým, že v severnej časti je lepšia dopravná dostupnost' (R1), viac pracovných príležitostí a lepšie podmienky pre život.

V okresoch južnej časti kraja sa začína formovat’ región chudoby smerujúci na severovýchod a juhovýchod Slovenska. Okresy nami vyčleneného pásu chudoby sa vyznačujú poddimenzovanou ekonomickou situáciou, nevyhovujúcou hospodárskou základňou, nedostatkom pracovných príležitostí v mieste bydliska, nízkou mobilitou obyvatel'stva za prácou ako aj výraznou sociálnou odkázanost'ou vel'kej časti obyvatel'stva. Tieto nepriaznivé podmienky výrazne ovplyvnila hospodárska kríza, ktorá sa na Slovensku začala naplno prejavovat’ v roku 2009.

\section{Literatúra}

BACSÓ, P. 2008. Kvalita života ako indikátor TUR obvodu Štúrovo. Dizertačná práca. Nitra: FPV UKF v Nitre, 2008. $171 \mathrm{s.}$

CZAKOVÁ, G. 2007. Migračný pohyb obyvatel'stva Nitrianskeho kraja v roku 2005. In Geografické informácie 11. Nitra: UKF v Nitre, 2007. s. 37-43. ISBN 978-80-8094-137-6.

EU-SILC. 2018. Zistovanie o príjmoch a životných podmienkach domácností v SR. [online]. [cit. 2018-03-10]. Dostupné na internete: https://ec.europa.eu/eurostat /web/income-and-living-conditions/data/database

FALŤAN, L. - PAŠIAK, J. 2004. Regionálny rozvoj Slovenska východiská a súčasný stav. Bratislava: Sociologický ústav SAV, 2004. 88 s. ISBN 80-8554435-0

HALUŠKOVÁ, E. - BOŽIK, J. 2015. Chudoba, spoločenské súvislosti a sociálne politiky na jej odstránenie. Bratislava: IRIS, 2015. s. 17-85. ISBN 978-808153-040-1.

JURČOVÁ, D. 2005. Slovník demografických pojmov. Bratislava: Inštitút informatiky a štatistiky, 2005. 72 s. ISBN 80-85659-40-9.

MAREŠ, P. 1999. Sociologie nerovnosti a chudoby. Praha: Sociologické nakladatelství SLON, 1999. 241 s. ISBN 80-85850-61-3.

MICHÁLEK, A. 2005. Koncentrácia a atribúty chudoby v Slovenskej republiky na lokálnej úrovni. In Geografický časopis. ISSN 0016-7192, 2005, roč. 57, č. 1, s. 3-22.

NÉMETHOVÁ, J. - PULPITLOVÁ, M. 1999. Domový, bytový fond a bytová výstavba v okrese Zlaté Moravce. Brno: Masarykova univerzita, 1999. s. 197201. ISBN 80-210-138-1.

NOVEZAMKY.DNES24.SK. 2016. Ako si žijeme na Slovensku? Nitriansky kraj sa nachádza v strednom pásme miery rizika chudoby. [online]. 2016, [cit. 2018-03-30]. Dostupné na internete: http://novezamky.dnes24.sk/ako-sizijeme-na-slovensku-nitriansky-kraj-sa-nachadza-v-strednom-pasme-miery- 
rizika-chudoby-238212

ROCHOVSKÁ, A. 2004. Vybrané aspekty chudoby na Slovensku z bližším zretel’om na ženy. Dizertačná práca. Bratislava: PriF UK, 2004. $170 \mathrm{~s}$.

ŠTATISTICKÝ ÚRAD SLOVENSKEJ REPUBLIKY. 2018. Datacube. [online]. [cit. 2018-03-10]. Dostupné na internete: http://datacube.statistics.sk/ TM1WebSK/TM1WebLogin.aspx

TOMEŠ, I. 2010. Úvod do teorie a metodologie sociální politiky. Praha: Portál, s.r.o., 2010. s. 254-260. ISBN 978-80 -7367-680-3.

TOWNSEND, P. 1987. Deprivation. In Journal of Social Policy. vol. 16, no. 2, pp. 125-146.

UZNESENIE vlády 655/1997 k návrh uplatňovaniu AGENDY 21 a vyhodnocovania ukazovatel'ov TUR v SR.

VESELOVSKÝ, J. 2012. Chudoba na príklade Nitrianskeho kraja. Nitra: UKF v Nitre, 2012. 145 s. ISBN 978-80558-0056-1.

VILINOVÁ, K. - SOTÁK, R. 2008. Developmental aspects of circulatory system mortality according to the age structure and regional disparities in Slovakia. In Geography in Czechia and Slovakia: Theory of practise at the Onset of 21st Century. Brno: Masarykova univerzita, 2008. s. 388-393. ISBN 978-80-2104600.

ŽILOVÁ, A. - NOVOTNÁ, A. - JOSEPH, M. 2014. In the period of social and demographic transformation of the society. In European and Global Contexts of Poverty. Milano: EDUCatt, 2014. pp. 7-78. ISBN 978-88-6780-072-8.

\section{STATUS OF THE NITRA SELF-GOVERNING REGION IN TERMS OF OBJECTIVE POVERTY}

\section{Summary}

The poverty risk rate in the region reached $14.6 \%$ in 2017 , which represents a higher risk of poverty than the average of the Slovak Republic (12.7\%) (www.statistics.sk). From all regions of Slovakia, the Nitriansky samosprávny kraj was ranked fourth in rank, with the highest risk of poverty. In absolute figures, this represents a total of 96,303 people who have been at risk of poverty in the Nitra region.

From the point of view of the spatial differentiation of poverty in the districts of the Nitra region, we are the best, most distant, showing the districts of the northwest to the central part of the county. From the point of view of the spatial differentiation of poverty in the districts of the Nitra region, we are the best, most distant, showing the districts of the northwest to the central part of the county. In particular, the districts of Nitra, Šal'a and Topol'čany, which can be said to belong among the districts with the most potent indicators from the point of view of poverty. Districts with unfavorable poverty differentiation are 
concentrated in the south of the region. These include the districts of Komárno, Levice and Nové Zámky which, on the basis of certain indicators, achieved the least satisfactory results.

From the above-mentioned analysis of the districts of the Nitra region, we can say that the richer districts are located in the northern part, and the poorer districts are located in the southern part of the Nitra self-governing region. This is due to the fact that in the northern part there is better transport availability (R1), more job opportunities and better living conditions.

In the districts of the southern part of the region a region of poverty is beginning to form towards the northeast and southeast of Slovakia. The districts of the poverty-stricken area are characterized by an underdeveloped economic situation, an inadequate economic base, a lack of job opportunities at the place of residence, a low mobility of the working population and a significant social dependence of a large part of the population. These unfavorable conditions have significantly affected the economic crisis, which started to show up in Slovakia in 2009.

\section{Bc. Nadežda Krajmerová}

Katedra geografie a regionálneho rozvoja FPV UKF v Nitre

Trieda A. Hlinku 1, 94974 Nitra

E-mail: nadezda.krajmerova@ student.ukf.sk

RNDr. PaedDr. Ján Veselovský, PhD.

Katedra cestovného ruchu

Fakulta stredoeurópskych štúdií

Univerzita Konštantína Filozofa v Nitre

Dražovská 4, 94974 Nitra

E-mail: jveselovský@ukf.sk 